This article has been publiched in the British Journal of Health Psychology 2009;14(4):625-64 and is available from: URL:

http://bpsoc.publisher.ingentaconnect.com/content/bpsoc/ bjhp

\title{
Evidence-based selection of theories for designing behaviour change interventions: Using methods based on theoretical construct domains to understand clinicians' blood transfusion behaviour
}

Jill J Francis ${ }^{1}$, Charlotte Stockton ${ }^{2}$, Martin P Eccles ${ }^{3}$, Marie Johnston $^{2}$, Brian H Cuthbertson ${ }^{1,4}$, Jeremy M Grimshaw ${ }^{5}$, Chris Hyde $^{6}$, Alan Tinmouth ${ }^{5}$ and Simon J Stanworth ${ }^{6}$

${ }^{1}$ Health Services Research Unit, University of Aberdeen

${ }^{2}$ College of Life Sciences and Medicine, University of Aberdeen

${ }^{3}$ Institute of Health and Society, Newcastle University ${ }^{4}$ Intensive Care Unit, Aberdeen Royal Infirmary, Aberdeen ${ }^{5}$ Clinical Epidemiology Programme, Ottawa Health Research Institute and Department of Medicine, University of Ottawa, Ottawa, Canada

${ }^{6}$ National Blood Transfusion Service, Oxford 
Word count (exc. figures/tables): 4,111

*Requests for reprints should be addressed to Jill Francis, Health Services Research Unit, Health Psychology Group, University of Aberdeen, $3^{\text {rd }}$ Floor, Health Sciences Building, Foresterhill, Aberdeen, AB25 2ZD, United Kingdom. (e-mail: j.francis@abdn.ac.uk).

\section{Acknowledgements}

This study was funded by the English Department of Health. We thank the participants for generously sharing their views. Jill Francis is $50 \%$ funded by the Chief Scientist Office of the Scottish Government Health Directorates. Jeremy Grimshaw holds a Canada Research Chair. The views expressed are not necessarily those of the funding bodies. 


\section{Abstract}

\section{Background:}

Many theories of behaviour are potentially relevant to predictive and intervention studies but most studies investigate a narrow range of theories. Michie et al. (2005) agreed 12 "theoretical domains" from 33 theories that explain behaviour change. They developed a "theoretical domains interview"(TDI) for identifying relevant domains for specific clinical behaviours, but the framework has not been used for selecting theories for predictive studies. It was used here to investigate clinicians' transfusion behaviour in intensive care units. Evidence suggests that red blood cells transfusion could be reduced for some patients without reducing quality of care.

\section{Objectives:}

1. To identify the domains relevant to transfusion practice in intensive care units (ICUs) and neonatal intensive care units (NICUs), using the TDI.

2. To use the identified domains to select appropriate theories for a study predicting transfusion behaviour.

\section{Methods:}

An adapted TDI about managing a patient with borderline haemoglobin by watching and waiting instead of transfusing red blood cells was used to conduct semistructured, one-to-one interviews with 18 intensive care consultants and neonatologists across the UK.

\section{Results:}

Relevant theoretical domains were: knowledge, beliefs about capabilities, beliefs about consequences, social influences, behavioural regulation. Further analysis at the construct level resulted in selection of seven theoretical approaches relevant to this context: Knowledge-Attitude-Behaviour model, Theory of Planned Behaviour, Social Cognitive Theory, Operant Learning Theory, Control Theory, Normative Model of Work Team Effectiveness and Action planning approaches. 
BRITISH JOURNAL OF HEALTH DSYCHOLOGY 2009: 14, 625-646.

\section{Conclusions:}

This study illustrated the use of the TDI to identify relevant domains in a complex area of inpatient care. This approach is potentially valuable for selecting theories relevant to predictive studies and resulted in greater breadth of potential explanations than would be achieved if a single theoretical model had been adopted.

\section{Keywords:}

Theory; clinical behaviour; semi-structured interviews; transfusion practice; evidencebased health care 
Evidence-based selection of theories for designing behaviour change interventions: Using methods based on theoretical construct domains to understand clinicians' blood transfusion behaviour

Health psychology offers a large number of theories to predict, explain or achieve health-related behaviour change. This presents at least two problems for researchers who wish to use theory to design behaviour change interventions. First, it is impossible to use all the potentially relevant theories to investigate the behaviour targeted for change. Second, there is no systematic basis on which to select the most relevant, important or useful theories for changing a particular behaviour. Researchers are thus likely to adopt a small number of theories on which to base their investigations. For example, in studies of health professional behaviour, studies typically investigate one or two theories (e.g., the Theory of Planned Behaviour and/or the Theory of Interpersonal Behaviour; Godin, Belanger-Gravel, Eccles \& Grimshaw 2008). An exception is the PRIME study, which simultaneously tested six theoretical frameworks (Bonetti, Pitts, Eccles, Grimshaw, Johnston, Steen, et al. 2006; Eccles, Grimshaw, Johnston, Steen, Pitts, Thomas, et al. 2007). These frameworks were selected to examine explanations that focused on factors influencing motivation (Theory of Planned Behaviour, Social Cognitive Theory), or action, (Operant Learning Theory, Implementation Intention and the Common Sense Self-Regulation Model) or stages of change. The justification for selecting these theories was solid (Walker, Grimshaw, Johnston, Pitts, Steen \& Eccles, 2003). First, all had been rigorously evaluated in other settings. Second, they all explain behaviour in terms of factors that are amenable to change. Third, they all include non-volitional components, i.e., they assume that individuals do not always have complete control over their actions. At a later date Michie, Johnston, Abraham, Lawton, Parker, Walker, et al. (2005) proposed a wider range of theories relevant to clinicians' behaviour in implementing evidence. However, there is still not a clear method for selecting theories most likely to be relevant to a particular clinical action. 
One possible method is to take a more inclusive approach to selecting theory. The present study used the comprehensive set of theoretical construct domains developed by Michie et al. (2005) to identify the domains most relevant to a clinical behaviour, and then mapped these domains on to theories of behaviour. These methods were used to select the theories most relevant to investigating and changing the target behaviour. The specific clinical behaviour under investigation was the transfusion of red blood cells in patients in intensive care units (ICU) and neonatal intensive care units (NICU).

Michie et al. (2005) used a systematic consensus methodology to agree 12 "theoretical construct domains" from 33 theories (covering 128 theoretical constructs) that may explain health-related behaviour change (Table 1, Column 1). This group developed a set of interview questions for identifying domains relevant to changing specific evidence-based clinical behaviours (e.g., implementation of the NICE schizophrenia guidelines; Michie, Pilling, Garety, Whitty, Eccles, Johnston, et al. 2007). This set of questions is hereafter referred to as the "Theoretical Domains Interview" (TDI), where 'domain' is defined as "encompassing a set of similar theoretical constructs" (Michie et al., 2005, p. 28). Data from the TDI may be used to identify the theoretical domains that are most likely to be relevant to the behaviour under investigation, so that they can be studied systematically, thereby strengthening the evidence base for the selection of appropriate behaviour change techniques in the design of behaviour change interventions (Michie, Johnston, Francis \& Hardeman, 2008).

The consensus methods used in developing the 12 theoretical domains were designed to include broad coverage of theories and constructs relating to behaviour and behaviour change in the implementation of clinical guidelines. This 
comprehensive set of domains thus provides a basis for acquiring empirical evidence to inform systematic selection of theories to investigate behaviour change in a particular healthcare context.

This approach has formed the basis of recent work on developing behaviour change interventions to implement evidence-based healthcare (Foy, Francis, Johnston, Eccles, Lecouturier, Bamford, Grimshaw, 2007; Hrisos, Eccles, Johnston, Francis, Kaner, Steen, Grimshaw, 2008; McKenzie, French, O'Connor, Grimshaw, Mortimer, Michie, Francis, et al. 2008). It makes an important contribution to current thinking about the development of complex interventions to improve health. The UK MRC guidance for developing complex interventions (Medical Research Council, 2008) argues that using a theoretical basis for identifying the factors that influence behaviour and for selecting interventions can increase the chances of a complex intervention being appropriate for a specific behaviour and thereby increase its chances of success. Using a theoretical basis also increases the cost effectiveness of developing and implementing an intervention since the mechanisms by which it succeeds are better understood.

However, although the TDI approach has been used to identify behaviour change techniques, it has not yet been used as an evidence base for selecting whole theories most likely to be relevant to the clinical behaviour under investigation. Thus, the objectives of this study were to (1) adapt the interview questions to one area of complex in-patient hospital care: blood transfusion practice; (2) develop a method for selecting theories based on the theoretical domains identified as relevant.

This study used the theoretical domains as the basis for a series of interviews that were conducted to identify appropriate theories. An integral part of the study included 
clearly specifying the behaviour of interest. The clinical behaviour was specified in the light of evidence about transfusion practice which, whilst varied, supports reduction of blood transfusions in some situations (Hébert, Wells, Blajchman, Marshall, Martin, Pagliarello et al., 1999; Hébert, Fergusson, Stather, McIntyre, Martin, Doucette et al. 2005; Kirpalani, Whyte, Andersen, Asztalos, Heddle, Blajchman et al 2006; Lacroix, Hébert, Hutchison, Hume, Tucci, Ducruet et al., 2007). The clinical behaviour of interest was thus specified as "managing a patient with borderline haemoglobin by watching and waiting instead of transfusing red cells".

Two groups of clinicians were selected for this interview study - intensive care consultants and neonatologists. These two groups of clinicians are significant users of blood products (Wallis, Wells, \& Chapman, 2006; Walsh, Garrioch, Maciver, Lee, MacKirdy, McClelland, et al., 2004). The study involved two methodological developments compared with previous research. First, the TDI was adapted to suit a clinical situation in which guidelines are based on limited high quality evidence. Second, the domains identified as relevant to transfusion behaviour were used as an empirical basis for selecting theories most likely to inform studies to predict and change this behaviour.

\section{Methods}

\section{Design}

This was an interview study using semi-structured one-to-one interviews, based on the theoretical domains, with intensive care consultants and neonatal consultants.

\section{Participants}

Eleven intensive care consultants (10 male, 1 female) and 7 neonatal consultants (5 male, 2 female) from hospitals across England (53\%) and Scotland (47\%) were 
recruited to take part in the semi-structured interviews. Consultants were aged 36-52 years $($ mean $=44.42, S D=4.71)$, and their experience as consultants ranged from 1 to 21 years $($ mean $=9.26, S D=5.12)$. The 18 participants were a purposive sample identified by clinicians on the research team and were selected because they were considered to represent a broad range of views and attitudes towards transfusion practice, reflecting their different ages, hospitals and regions.

\section{Materials}

An interview topic guide was developed (see Table 1), based on the 12 theoretical domains, to elicit two kinds of beliefs: (i) general beliefs about the relevance of each domain for the behaviour; and (ii) if relevant, specific beliefs to give greater detail about the role of the domain in influencing the behaviour. The TDI was adapted for the specified behaviour and clinical contexts, as pilot testing (by CS) of a first draft of the questions using the original TDI wording indicated that they did not always fit the context. For example, some clinicians indicated that they used not only guidelines but also local protocols, or that they had changed their practice already based on evidence from one of the clinical trials rather than because of a guideline. Clinician informants and clinicians on the researcher team made suggestions for rewording some questions and these suggestions were discussed by the team to ensure that they retained the original meaning of each theoretical domain. The adapted TDI was further piloted and question wording was refined to enhance clarity.

\section{TABLE 1 HERE}

\section{Procedure}

Participants were contacted in writing and invited to an interview about their clinical decision making in relation to transfusion practice. All interviews were conducted (by CS) using the interview topic guide (Table 1), in an office at participants' places of work to maintain privacy and confidentiality. Interviews were recorded using a digital 
recording device (Olympus Voice \& Music DM-20) and lasted between 24 and 56 minutes $(M=39 ; S D=9)$. A second researcher $(\mathrm{JF})$ listened to the recordings of the first two interviews to check fidelity of the use of the topic guide. The recordings were transcribed and anonymised.

\section{Analysis}

Stage 1. One researcher (CS) content analysed the transcriptions by classifying the utterances into the theoretical domains. The relevant domains were identified based on the content of the beliefs elicited. A domain was considered 'relevant' if frequently mentioned responses indicated that it might affect performance of the clinical behaviour.

Stage 2. First, the beliefs were used to identify constructs within each relevant theoretical domain. We provided three researchers (two psychologists and one clinical non-psychologist) with a list of the beliefs (from the Stage 1 analysis) and the list of constructs from the original TDI paper (Michie et al., 2005, Table 1) and asked them to work independently to match the beliefs with the constructs. Specific constructs from the relevant domains were listed and discussed by the research team to agree the theoretical models that represented these constructs. This discussion was based on the list of theories provided in the Appendix to the TDI paper.

\section{Ethics}

The study was approved by the West Glasgow Ethics Committee 1 and by each individual Research and Development office of the 5 UK NHS Trusts/Health Boards from which participants were drawn.

\section{Results}

\section{Stage 1: Identification of relevant construct domains}


Quotations from the transcripts to illustrate each theoretical domain are reported in Tables 2 and 3 below. The frequency with which each belief was mentioned is presented in the final column of each table. Together, frequency and content (e.g., Do the responses suggest an issue or problem? Is there likely to be variance among clinicians?) were used to identify a domain as relevant or not.

\section{TABLE 2 HERE}

\section{TABLE 3 HERE}

(a) Domains reported not to influence a change in practice.

Skill was not an issue for this behaviour, which was consistently described as very straightforward and normal. With respect to the domain, motivation and goals, most participants reported that the behaviour was important, suggesting that this domain is not problematic. For memory, attention and decision processes, participants were very fluent about the issues that they consider, suggesting that simply forgetting to do the target behaviour is not a problem in this context. When asked about environmental context and resources, participants consistently talked about the clinical context (e.g., the speed at which the haemoglobin is falling; the idea that the patient will have many other clinical problems) rather than the environmental context or problems with resources. This suggests that issues of resource and environment are not perceived as a barrier to watching and waiting instead of transfusing. Emotion was discussed in terms of concern (about the patient) but not in terms of the consultants' own emotions (stress or anxiety). When responding to questions about the nature of the behaviour, participants tended to repeat or continue the responses they offered for the domain, behavioural regulation. These answers thus did not add new information.

(b) Domains reported to influence a change in practice. 
As seen in Table 2, intensive care consultants in the sample were aware of the evidence base relating to transfusion practice. However, Table 3 shows that this was a more problematic domain for the neonatology group. Most mentioned knowledge as a potential barrier to changing transfusion practice and noted that knowledge about the evidence was variable. Neonatologists were often not convinced about the evidence base. The two groups of consultants reported similar views about the remaining domains. Views on beliefs about capabilities were variable, ranging from absolutely confident to elaboration in the form of the difficulty would be if ... and also confident most of the time. This variability suggested that the domain may be relevant. When discussing beliefs about consequences (risks and benefits), participants talked a lot and gave specific examples, suggesting that this domain may represent one of the important ways that they think about this behaviour. Social influences appeared to be a relevant domain, partly as consultants may discuss details with relatives, but mostly as the decision tends to be discussed and agreed by clinical teams.

For behavioural regulation, in terms of the strategies that consultants might adopt to achieve change, most consultants were able to generate alternative behaviours that might assist change. They also consistently referred again to the evidence base (i.e. the domains knowledge and beliefs about consequences) in response to questions about achieving change. Some felt that their first step in adopting the change would be a review of current practice. This suggests that the domain might be applicable to the way change could be effected in this context, and thus behavioural regulation was judged to be a relevant domain.

In summary, the theoretical domains that were identified and subsequently used to map back to the theories were knowledge (of the evidence); beliefs about capabilities; beliefs about consequences; social influences and behavioural regulation. 
(c) Domains for which reported influence is unclear.

Responses to questions for the domain professional role and identity were not very informative, as they did not identify whether following the evidence (in favour of more restrictive transfusion practice) would be consistent or inconsistent with professional roles. Some reported that watching and waiting is normal for them. From this we inferred that professional role issues may not be a problem for the behaviour of watching and waiting instead of transfusing.

\section{Stage 2:}

Table 4 (Column 6) presents the results of the three coders in matching the elicited beliefs with constructs within each domain. The agreement reached by four researchers (JF, CS, MJ, MPE) about which theories best represent the constructs is also reported in Table 4 (Column 6).

\section{TABLE 4 HERE}

Table 4 shows that there was substantial agreement between coders, given the large number of constructs in each domain. All three coders agreed constructs relating to 7 of the 21 beliefs. Two out of three agreed constructs relating to 10 beliefs. There was no agreement for four of the beliefs (or more accurately, two beliefs that were elicited from both ICU and NICU interviews): Disadvantages of watching \& waiting: The patient's condition deteriorates; and I would need good, new evidence from research that my transfusion practice needs to change. This disagreement occurred in two theoretical domains comprising a large number of constructs (13 and 10 for beliefs about consequences and behavioural regulation, respectively). 
When full literal agreement was not obtained we checked whether all the identified constructs fell within a single theory. For example, within beliefs about consequences the named constructs included attitude (reflecting global evaluation, equivalent to the 'direct' approach to attitude measurement in the Theory of Planned Behaviour) and outcome expectations (reflecting specific perceived consequences). Outcome expectations can be considered as equivalent to Behavioural beliefs, which are compatible with the 'indirect' approach to attitude measurement in the Theory of Planned Behaviour. Similarly, feedback, action planning and goal setting (within behavioural regulation) are all constructs from Control Theory (Carver \& Scheier, 1981)

\section{Identification of relevant theories}

The research team discussion to agree theories that are relevant to transfusion practice took into account the following components of Table 4. The identification of Attitude, Subjective norm and Perceived behavioural control suggested the Theory of Planned Behaviour (Ajzen, 1991). The identification of Outcome expectancy and Self-efficacy suggested Social Cognitive Theory (Bandura, 1998). In addition, knowledge is part of the intuitive 'knowledge-attitude-behaviour' model (e.g., Johnston, Leung, Fielding, Tin, \& Ho, 2003). Together, Outcome expectancies and Feedback imply that behaviour may also be influenced by rewards, suggesting that Operant Learning Theory (Skinner, 1953) may be applicable. However, as this theory proposes that processes of behaviour change bypass the cognitive route, further investigation would be needed to assess the relevance of this theory in the current context of self-reported views. Team working was identified as important (e.g., the Normative Model of Work Team Effectiveness; Hackman, 1983). Finally, within the domain, behavioural regulation, the named constructs were all part of Control Theory (Carver \& Scheier, 1981). It was also decided that these constructs implied an action 
planning approach (Gollwitzer, 1999; Sniehotta, Scholz, Schwarzer, 2006) for planning alternative behaviours could be relevant to changing transfusion behaviour.

\section{Discussion}

The rich variety of theories, which may form a basis for investigations about health behaviour and behaviour change, results in a challenge to the science of behaviour change. We need more systematic methods for selecting the most appropriate theories to develop interventions for changing specific behaviours. This will ensure that we consider those of greatest relevance to the behaviour and the context. The TDI provides a basis for such methods.

The current study further developed these methods by operationalising the domains in a complex area of inpatient care where high quality evidence is still emerging, and by using the interview data to identify not only the domains relevant to the behaviour but also specific constructs and theories implied by the data. These methods were used in the context of evidence about a need for change in transfusion practice in intensive care and in neonatology. Given that, over the 12 domains, there are 128 constructs, agreement reached between coders was reasonable. Even where there was disagreement, the coding provided further guidance in selecting theories. As the domains are made up of overlapping constructs (indeed, this was the rationale behind the theoretical domains project), full agreement was unlikely at the literal level. During the coding exercise it became evident that a more fully referenced list - or an agreed set of definitions of constructs - would be valuable in conducting this kind of work and may assist in enhancing agreement between coders.

The adapted TDI identified five of the 12 theoretical construct domains as potentially relevant to transfusion practice. However, there are problems in replacing established theories with the theoretical domains approach. First, the framework 
does not specify the relationships between the theoretical construct domains, as would occur in a theory. For example, the Theory of Planned Behaviour (Ajzen, 1991) specifies that intention is directly related to behaviour whereas the relationships between behaviour and all other constructs in the model are mediated partly or fully through intention. By contrast, the theoretical domains approach does not identify such patterns, therefore does not guide analysis, and thus is not an attempt to replace theories. Hence a further step is needed to move from an investigation based on the TDI to identify theories that are relevant to the target behaviour.

Second, the TDI was designed for situations in which guidelines for clinical practice are based on extensive and high quality clinical evidence. The theoretical domains may be of less utility in situations where the evidence to support guideline development is less clear-cut, as it is possible that the effect of potential predictors may be overwhelmed by the influence of variations in attitude (i.e., different beliefs about the consequences of more restrictive transfusion practice). Hence, it was possible that consideration of a broad range of factors in this context would be fruitless. However, from analysis of the interview data, there was evidence that a range of domains, as well as of beliefs about consequences, were relevant.

Analysis of the interview data also indicated that specific constructs nested within the relevant domains were applicable to transfusion behaviour in this context. This led to the selection of seven theoretical frameworks as appropriate for further investigation of transfusion behaviour by critical care consultants. The seven frameworks were: the Theory of Planned Behaviour (Ajzen, 1991); the intuitive Knowledge-AttitudeBehaviour model (Johnston et al., 2003); Social Cognitive Theory (Bandura, 1998); Operant Learning Theory (Skinner, 1953); Normative Model of Work Team Effectiveness (Hackman, 1983), Control Theory (Carver \& Scheier, 1981) and Action 
Planning approaches (Gollwitzer, 1999; Sniehotta et al., 2006). It is perhaps not surprising that these theories emerged as relevant. Most of them have amassed a large evidence base not only for health-related behaviours in general but also for clinical behaviours in particular (e.g., Bonetti et al., 2006; Eccles et al., 2007, Walker, Grimshaw \& Armstrong, 2001).

\section{What, then, can be learned from this study?}

With respect to transfusion practice in ICU and NICU, and in particular for patients with borderline haemoglobin, clinical evidence suggests that it is advisable to watch and wait instead of transfusing more often than occurs in current practice. Changing current behaviour first requires an understanding of the factors most likely to influence practice. This study provides some evidence that the key factors are knowledge of the evidence base (in particular, in the context of neonatology), beliefs about the consequences of monitoring rather than transfusing (particularly, avoiding the risks associated with transfusion), beliefs about capabilities (particularly, when the patient's condition is unstable), social influences (particularly, the influence of the clinical team) and behavioural regulation (particularly, the use of self-monitoring, feedback and planning alternative patient management strategies). Interventions designed to change practice are therefore more likely to be effective if they target these domains. Interventions are less likely to be effective if they target the domains for which there is no evidence of relevance: skills; motivation and goals; memory, attention and decision processes; environmental context and resources; emotion; and nature of the behaviour.

To date, the largest evidence base relating to guideline dissemination and implementation strategies (Grimshaw, Thomas, MacLennan, Fraser, Ramsay, Vale et al., 2004) was a systematic review of 235 studies reporting 309 comparisons. This review identified that approximately $86 \%$ of interventions resulted in improved health 
care. However, considerable variation in effects led these authors to recommend the development of "a coherent theoretical framework of health professional and organisational behaviour and behaviour change to inform better choice of interventions" (p. 4). The current study is one attempt to develop a method for selecting such a theoretical framework.

At the methodological level, this study shows that, for problem-driven research (such as behaviour change that is needed for clinicians to translate medical evidence into practice), taking a broad and systematic approach to the selection of appropriate theories may be fruitful. In particular, using the theoretical domains framework resulted in greater breadth of potential explanations than would be achieved if only a single theoretical model had been adopted. However, although we have tried to describe the consensus methods used to select these theories, this is only the start of a process that we hope will result in a clearly definable, replicable method. We would not argue that the methods used here were perfect, merely that they are an improvement on the common practice of using a limited range of theories to address a problem of behaviour change. In particular, lack of inter-rater reliability data was a limitation.

A further note of caution is needed. The theoretical domains interview (TDI) generates hypotheses about the factors influencing behaviour; it does not identify evidence that these are influences. The interviews elicit attributions (Weiner, 1986) that clinicians make about their own and others' clinical behaviours. This provides important information about how people explain their own behaviour and what they think might change it, but is not as convincing as a predictive quantitative study designed to identify the variables that predict the behaviour, or an experimental study that intervenes to change behaviour. Hence, the importance of this approach lies in the potential for improving the efficiency and effectiveness with which certain theories 
are selected to predict, explain and change behaviour. Thus, we plan to follow this study with an empirical predictive study using the identified theoretical frameworks to predict clinical transfusion behaviour in ICU and NICU.

Furthermore, many theories predict or explain behaviour (thereby identifying the constructs to target for change) and there are many techniques that can change behaviour, but there are few theories that incorporate the techniques of change. (Notable exceptions are Learning theory, Skinner 1953, Social Cognitive Theory, Bandura 1998 and Control Theory, Carver \& Scheier 1981.) Hence, the selection of appropriate behaviour change techniques involves an additional step: mapping predictor constructs on to behaviour change techniques (Michie et al., 2008).

In conclusion, the 'theoretical domains' approach has identified theories that appear to be relevant to transfusion behaviour. It has generated hypotheses about influential factors that can be systematically investigated in future studies designed to predict and change transfusion practice in adult and neonatal intensive care units. These principles are potentially generalisable to a range of other health contexts. 


\section{References}

Ajzen, I. (1991). The theory of planned behaviour. Organisational Behaviour and Human Decision Processes, 50, 179-211.

Bandura, A. (1998). Health promotion from the perspective of social cognitive theory. Psychology and Health, 13, 623-649.

Bell, E. F., Strauss, R. G., Widness, J. A., Mahoney, L. T., Mock, D. M., Seward, V. J., et al. (2005). Randomized trial of liberal versus restrictive guidelines for red blood cell transfusion in preterm infants. Pediatrics, 115(6), 1685-1691.

Bonetti, D., Pitts, N.B., Eccles, M., Grimshaw, J., Johnston, M., Steen, N., Glidewell, L., Thomas, R., Maclennan, G., Clarkson, J.E., \& Walker, A. (2006). Applying psychological theory to evidence-based clinical practice: Identifying factors predictive of taking intra-oral radiographs. Social Science \& Medicine, 63, 18891899.

Carson, J.L., Terrin, M.L., Magaziner, J. (2003). Anemia and postoperative rehabilitation. Canadian Journal of Anesthesia, 50, s60-s64.

Carver, C.S., \& Scheier, M.F. (1981). Attention and self-regulation: A control theory approach to human behavior. New York: Springer-Verlag.

Davies, P.A., Walker, A.E., \& Grimshaw, J.M. (2003). Theories of behaviour change in studies of guideline implementation. The British Psychological Society 2003 Proceedings, 120.

Eccles, M.P., Grimshaw, J.M., Johnston, M., Steen, N., Pitts, N.B., Thomas, R., Glidewell, E., MacLennan, G., Bonetti, D., \& Walker, A. (2007). Applying psychological theories to evidence-based clinical practice: Identifying factors predictive of managing upper respiratory tract infections without antibiotics. Implementation Science, 2:26

Foy, R., Francis, J.J., Johnston, M., Eccles, M., Lecouturier, J., Bamford, C., Grimshaw, J. (2007). The development of a theory-based intervention to promote 
appropriate disclosure of a diagnosis of dementia - BMC Health Services Research, 7:207.

Godin, G., Belanger-Gravel, A., Eccles, M.P., \& Grimshaw, J. (2008). Healthcare professionals' intention and behaviours: A systematic review of studies based on the social cognitive theories. Implementation Science, 3, 36.

Gollwitzer, P.M. (1999). Implementation intentions: Strong effects of simple plans. American Psychologist, 54, 493-503.

Grimshaw, J.M., Thomas, R.E., MacLennan, G., Fraser, C., Ramsay, C.R., Vale, L., et al. (2004). Effectiveness and efficiency of guideline dissemination and implementation strategies. Health Technology Assessment, 8, 1-84.

Hackman, J. R. (1983). A normative model of work team effectiveness. Research Program on Group Effectiveness. Yale School of Organization and Management. Hrisos, S., Eccles, M., Johnston, M., Francis, J.J., Kaner, E.F.S., Steen, N., \& Grimshaw, J. (2008). Developing the content of two behavioural interventions. Using theory-based interventions to promote GP management of upper respiratory tract infection without prescribing antibiotics \#1. BMC Health Services Research, 8:11.

Johnston, J.L., Leung, G.M., Fielding, R., Tin, K.Y., \& Ho, L. (2003). The development and validation of a knowledge, attitude and behaviour questionnaire to assess undergraduate evidence-based practice teaching and learning. Medical Education, 37, 992-1000.

Lacroix, J., Hébert, P.C., Hutchison, J.S., Hume, H.A., Tucci, M., Ducruet, T., et al. (2007). Transfusion strategies for patients in pediatric intensive care units. New England Journal of Medicine, 356, 1609-1619.

Llewelyn, C., Casbard, A., Wells, A., \& Williamson, L. (2005). The epidemiology and survival of transfusion recipients. (EASTR) study. Transfusion Medicine, 15 (Suppl. 1), 28. 
McKenzie, J.E., French, S.D., O'Connor, D.A., Grimshaw J.M., Mortimer, D., Michie, S., Francis, J., Spike, N., Schattner, P., Kent, P.M., Buchbinder, R., Green, S.E. (2008) IMPLEmenting a clinical practice guideline for acute low back pain evidence-based manageMENT in general practice (IMPLEMENT): cluster randomised controlled trial study protocol. Implementation Science, 3:11.

Medical Research Council. (2008). Developing and evaluating complex interventions: new guidance. London: Medical Research Council.

Michie, S., Johnston, M., Abraham, C., Lawton, R., Parker, D., Walker, A., et al. (2005). Making psychological theory useful for implementing evidence based practice: A consensus approach. Quality and Safety in Health Care, 14, 26-33.

Michie, S., Johnston, M., Francis, J.J., Hardeman, W., Eccles, M.P. (2008). From theory to intervention: mapping theoretically derived behavioural determinants to behaviour change techniques. Applied Psychology: an international review. Special Issue on "Conceptualizing Theory-Based Health Behavior Change Research", 57, 660-680.

Michie, S., Pilling, S., Garety, P., Whitty, P., Eccles, M. P., Johnston, M., et al. (2007). Difficulties implementing a mental health guideline: An exploratory investigation using psychological theory. Implementation Science, 2(8).

Skinner, B.F. (1953). Science and human behavior. New York: Macmillan.

Sniehotta, F.F., Scholz, U., \& Schwarzer, R. (2006). Action plans and coping plans for physical exercise: A longitudinal intervention study in cardiac-rehabilitation. British Journal of Health Psychology, 11, 23-37.

Walker, A.E., Grimshaw, J.M., \& Armstrong, E.M. (2001). Salient beliefs and intentions to prescribe antibiotics for patients with a sore throat. British Journal of Health Psychology, 6, 347-360.

Wallis, J.P., Wells, A.W., \& Chapman, C.E. (2006). Changing indications for red cell transfusion from 2000 to 2004 in the North of England. Transfusion Medicine, $16,411-417$. 
Walsh, T.S., Garrioch, M., Maciver, C., Lee, R.J., MacKirdy, F., McClelland, D.B., et al. (2004). Red cell requirements for intensive care units adhering to evidencebased transfusion guidelines. Transfusion, 44, 1405-1411.

Weiner, B. (1986). An attributional theory of motivation and emotion. New York: Springer-Verlag. 
Table 1. Interview topic guide used for semi-structured elicitation interviews with adult and neonatal intensive care consultants.

\begin{tabular}{|c|c|}
\hline $\begin{array}{l}\text { Construct } \\
\text { Domain }\end{array}$ & Interview Questions \\
\hline Knowledge & $\begin{array}{l}\text { "We have talked about some of the evidence, l'd also like to find out about your knowledge and } \\
\text { use of guidelines:" } \\
\text { - Do you use any guidelines (to inform your transfusion practice)? } \\
\text { - How do you use the guidelines? (i.e. what do you actually, physically do? Do you ever read } \\
\text { the guidelines to check if a behaviour you performed was guideline-compliant?) } \\
\text { - What other evidence are you aware of, or do you use? }\end{array}$ \\
\hline Skills & $\begin{array}{l}\text { How easy or difficult would it be to manage a patient with borderline } \mathrm{Hb} \text { by watching \& } \\
\text { waiting instead of transfusing RBCs? } \\
\text { What skills are required to manage a patient with borderline } \mathrm{Hb} \text { by watching \& waiting } \\
\text { instead of transfusing RBCs? }\end{array}$ \\
\hline $\begin{array}{l}\text { Sociall } \\
\text { professional } \\
\text { role and identity }\end{array}$ & $\begin{array}{l}\text { Do you sometimes feel constrained by guidelines?...What about protocols? } \\
\text { - How does this affect your professional autonomy? } \\
\text { - Is there anything else about your professional role that influences you managing patients } \\
\text { with borderline } \mathbf{H b} \text { by watching \& waiting instead of transfusing RBCs? (i.e. consensus } \\
\text { in your profession) }\end{array}$ \\
\hline $\begin{array}{l}\text { Beliefs about } \\
\text { capabilities }\end{array}$ & $\begin{array}{l}\text { How confident are you about doing this? (that you can manage a patient with borderline } \mathbf{H b} \\
\text { by watching \& waiting instead of transfusing RBCs, despite any difficulties) } \\
\text { - What problems/difficulties do you think you might encounter in managing a patient with } \\
\text { borderline } \mathbf{H b} \text { by watching \& waiting instead of transfusing RBCs? } \\
\text { - What would help you overcome these problems/difficulties? }\end{array}$ \\
\hline $\begin{array}{l}\text { Beliefs about } \\
\text { consequences }\end{array}$ & $\begin{array}{l}\text { What are the benefits of managing a patient with borderline } \mathbf{H b} \text { by watching \& waiting } \\
\text { instead of transfusing RBCs? } \\
\text { - ... to self, patients i.e. what harms might be avoided?, colleagues, healthcare organisation } \\
\text { [NHS] - positive \& negative, long-term \& short-term, financial. } \\
\text { What are the disadvantages of managing a patient with borderline } \mathbf{H b} \text { by watching \& } \\
\text { waiting instead of transfusing RBCs? } \\
\text { - ... to self, patients i.e. what harms might there be?, colleagues, healthcare organisation } \\
\text { [NHS] - positive \& negative, long-term \& short-term, financial } \\
\text { Are there any incentives to encourage managing a patient with borderline } \mathbf{H b} \text { by watching } \\
\text { \& waiting instead of transfusing RBCs? }\end{array}$ \\
\hline $\begin{array}{l}\text { Motivation and } \\
\text { goals }\end{array}$ & $\begin{array}{l}\text { How important do you feel it is to manage a patient with borderline Hb by watching \& } \\
\text { waiting instead of transfusing RBCs? (in relation to other behaviours required to treat the } \\
\text { patient). }\end{array}$ \\
\hline
\end{tabular}




\begin{tabular}{|c|c|}
\hline $\begin{array}{l}\text { Memory, } \\
\text { attention and } \\
\text { decision } \\
\text { processes }\end{array}$ & $\begin{array}{l}\text { What thought processes might guide your decision to manage a patient with borderline } \mathbf{H b} \\
\text { by watching \& waiting instead of transfusing RBCs? } \\
\text { - In what situations, if any, might it be difficult to think of alternatives to transfusing? } \\
\text { - Is managing a patient with borderline } \mathbf{H b} \text { by watching \& waiting instead of transfusing } \\
\text { RBCs something you would usually do? }\end{array}$ \\
\hline $\begin{array}{l}\text { Environmental } \\
\text { context and } \\
\text { resources }\end{array}$ & $\begin{array}{l}\text { In what way is managing a patient with borderline } \mathbf{H b} \text { by watching \& waiting instead of } \\
\text { transfusing RBCs affected by different clinical situations? (any other situations?) } \\
\text { - Are there any competing tasks or time constraints that influence whether you might manage } \\
\text { a patient with borderline } \mathbf{H b} \text { by watching \& waiting instead of transfusing RBCs? }\end{array}$ \\
\hline $\begin{array}{l}\text { Social } \\
\text { influences }\end{array}$ & $\begin{array}{l}\text { Would other team members have a view of you managing a patient with borderline } \mathbf{H b} \text { by } \\
\text { watching \& waiting instead of transfusing RBCs? } \\
\text { - who else? Other clinicians, medical staff, relatives, NBS? } \\
\text { - What do you think those views might be? } \\
\text { - How might the views of other team members affect you managing a patient with } \\
\text { borderline } \boldsymbol{H} \boldsymbol{b} \text { by watching \& waiting instead of transfusing RBCs? }\end{array}$ \\
\hline Emotion & $\begin{array}{l}\text { Would you feel worried about managing a patient with borderline } \mathbf{H b} \text { by watching \& } \\
\text { waiting instead of transfusing RBCs? } \\
\text { - If so, in what ways \& in what kind of circumstances? } \\
\text { - How would it influence your work stress to manage a patient with borderline } \mathrm{Hb} \text { by } \\
\text { watching \& waiting instead of transfusing RBCs? }\end{array}$ \\
\hline $\begin{array}{l}\text { Behavioural } \\
\text { regulation }\end{array}$ & $\begin{array}{l}\text { If you're thinking about changing your own transfusion practice, how would you do this? } \\
\text { - What might you do in order to reduce the likelihood of needing to transfuse? (NICU only) } \\
\text { - Are there procedures or ways of working that might encourage you to manage a patient } \\
\text { with borderline } \mathbf{H b} \text { by watching \& waiting instead of transfusing RBCs? }\end{array}$ \\
\hline $\begin{array}{l}\text { Nature of the } \\
\text { behaviour }\end{array}$ & $\begin{array}{l}\text { "The evidence from research suggests that transfusion practice is variable. However, there is } \\
\text { evidence to support a restrictive transfusion practice. With that in mind, in terms of aiming to } \\
\text { transfuse less:" } \\
\text { - What might need to be done differently? } \\
\text { - What would you do differently? } \\
\text { - Who needs to do what differently when, where, how, how often and with whom? }\end{array}$ \\
\hline
\end{tabular}

Note: Bold font denotes behaviour as specified. Font in italics denotes core questions. Dot points denote potential prompts. $\mathrm{RBCs}=$ red blood cells; $\mathrm{Hb}=$ Haemoglobin 
Table 2. Summary table of specific beliefs elicited from semi-structured interviews with 11 ICU consultants, allocated to the 12 theoretical domains.

\begin{tabular}{cc}
$\begin{array}{c}\text { Construct } \\
\text { Domain }\end{array}$ & Specific Belief Sample Quote \\
\hline Knowledge & Sare
\end{tabular}

I know about the TRICC trial and other evidence
"We are aware of the evidence base now in terms of transfusion thresholds" (ICU8, 51)

"the general principles of the TRICC trial are good and I think it made everybody just stop and think a little bit about what they were doing with transfusion" (ICU11, 51)

"there's been a couple of follow-up studies from TRICCs, there's the ATTICS stuff" (ICU12, 275)
Frequency (out of 11) 10

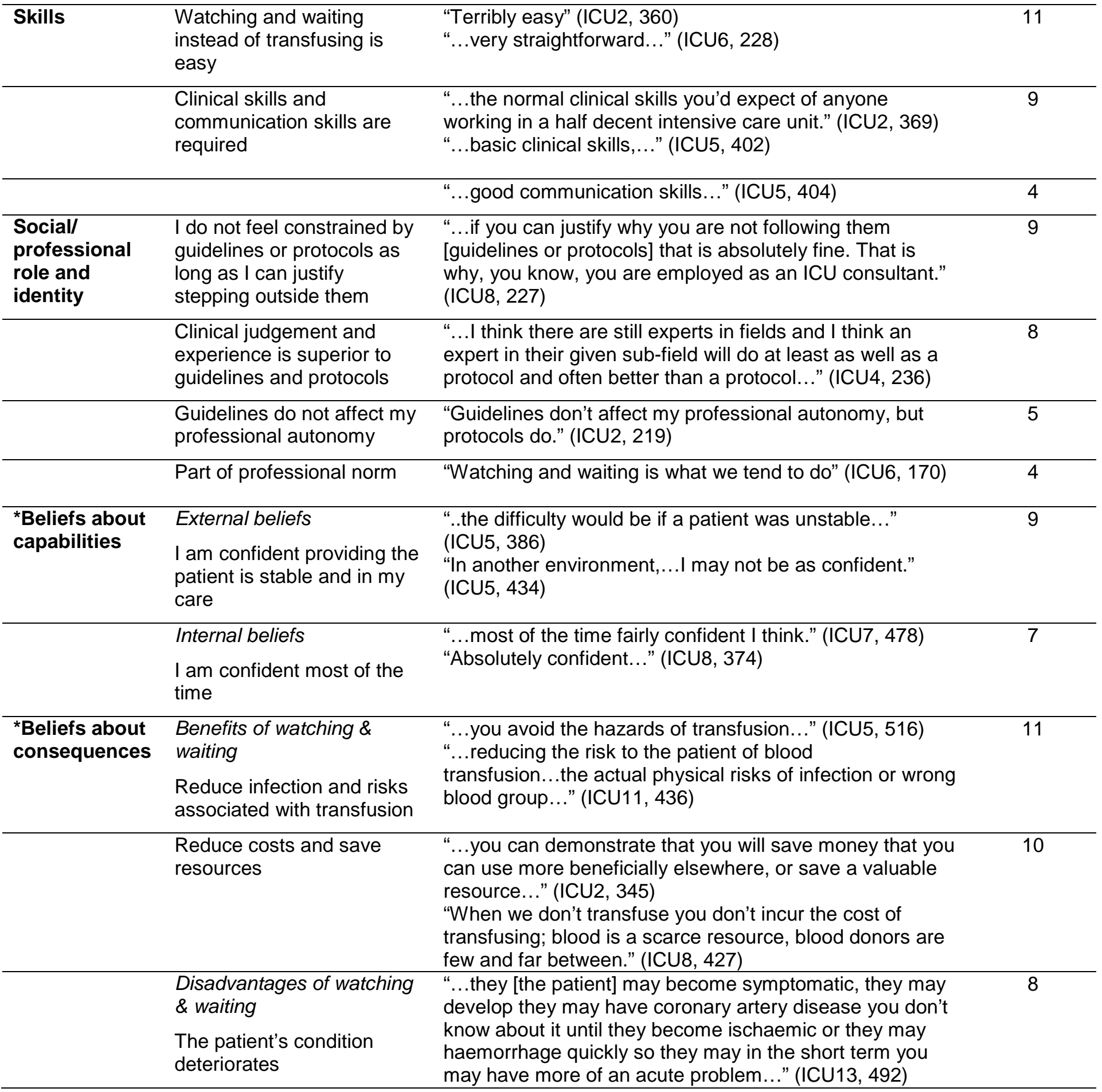




\begin{tabular}{ll}
\hline $\begin{array}{l}\text { Motivation } \\
\text { and goals }\end{array}$ & $\begin{array}{l}\text { It is important to watch and } \\
\text { wait }\end{array}$ \\
& \\
\hline & $\begin{array}{l}\text { It is not important, } \\
\text { compared to other things, } \\
\text { to watch and wait }\end{array}$ \\
\hline $\begin{array}{l}\text { Memory, } \\
\text { attention and } \\
\text { decision } \\
\text { processes }\end{array}$ & $\begin{array}{l}\text { The patient's whole } \\
\text { condition needs to be } \\
\text { considered, including } \\
\text { haemoglobin levels, clinical } \\
\text { context, patient history and } \\
\text { trajectory etc. }\end{array}$
\end{tabular}

Need to pay attention to patient's changing clinical condition \& be able to react quickly

"...based on the evidence that's available I think it is quite important..." (ICU3, 590)

"I think important because it sets a precedent a wee bit if you do it consistently then it just becomes the norm and then it doesn't become an issue at all." (ICU12, 673)

“...well, I don't think it's as important as doing many other things for this patient." (ICU4, 630)

"...it's down the list of, the main behaviours..." (ICU5, 583)

"So the chronic background things, the acute changes ad as I say maybe a little bit of what else is going on in the whole system." (ICU7, 610) "So predicting what the patient's going, what's going to happen to the patient both clinically and round about I think is important..." (ICU10, 554)

"...you have to be prepared to change if the patient's condition changes..." (ICU3, 601)

\begin{tabular}{ll}
\hline Environ- & Changes in the patient's \\
mental & clinical status, or \\
context and & haemoglobin trends will \\
resources & influence whether or not I \\
& watch and wait
\end{tabular}

"...the speed at which the haemoglobin is falling." (ICU4, 9 536)

“..the more chronic intensive care patient whose haemoglobin is drifting down,...you're more likely to watch and wait whereas if somebody is immediately post-op and their haemoglobin is you feel it is going to drop then you may well transfuse them a bit earlier." (ICU13, 462)

The patient's co- " "...this patient will have many, many other clinical morbidities, or pre-existing condition will influence whether or not I watch and wait

problems and issues..." (ICU4, 371)

"...I suppose acute coronary syndrome er, active bleeding, requirement for surgery, pre-existing conmorbidities...there's a whole bunch of sort of related things that'll alter your decision." (ICU7, 527)

\begin{tabular}{ll}
\hline $\begin{array}{l}\text { *Social } \\
\text { influences }\end{array}$ & $\begin{array}{l}\text { We often make decisions } \\
\text { as a team }\end{array}$ \\
\hline & $\begin{array}{l}\text { Advice is sometimes sought } \\
\text { from haematologists or } \\
\text { blood bank staff }\end{array}$
\end{tabular}
"...decisions are made in conjunction with other members of the team..." (ICU3, 261)

"If there was any doubt l'd pick up the phone and speak to a haematologist..." (ICU5, 370)
We listen to the opinions of relatives, but the consultant(s) make the final
"You would take on board what the relative said, but the final decision for transfusion would rest with you and your consultant colleagues." (ICU5, 302) decision

\begin{tabular}{|c|c|c|c|}
\hline \multirow[t]{3}{*}{ Emotion } & $\begin{array}{l}\text { Watching and waiting would } \\
\text { not add to my work stress }\end{array}$ & $\begin{array}{l}\text { "I don't see it as a stress. As I say it is part of the job..." } \\
\text { (ICU6, 498) } \\
\text { "It's not a major source of stress..." (ICU10, 602) }\end{array}$ & 8 \\
\hline & $\begin{array}{l}\text { I would not worry about } \\
\text { watching and waiting }\end{array}$ & $\begin{array}{l}\text { "I wouldn't be unduly worried about this particular } \\
\text { decision..." (ICU4, 741) } \\
\text { "I don't lose any sleep over it [watching \& waiting]." (ICU7, } \\
647 \text { ) }\end{array}$ & 7 \\
\hline & $\begin{array}{l}\text { I might be concerned in } \\
\text { some situations about } \\
\text { watching and waiting }\end{array}$ & $\begin{array}{l}\text { "...clearly when you've got a borderline patient, yes, you } \\
\text { should be concerned." (ICU6, 489) } \\
\text { "Yeah, I think if they went off to the ward in the middle of } \\
\text { the night I might be quite worried." (ICU12, 724) }\end{array}$ & 5 \\
\hline $\begin{array}{l}\text { *Behavioural } \\
\text { regulation }\end{array}$ & $\begin{array}{l}\text { I would need good, new } \\
\text { evidence from research that } \\
\text { my transfusion practice } \\
\text { needs to change }\end{array}$ & $\begin{array}{l}\text { "If I was going to change practice, it would have to be on } \\
\text { the basis of looking at the trials...it would have to be fairly } \\
\text { convincing evidence..." (ICU6, 238) }\end{array}$ & 10 \\
\hline
\end{tabular}




\begin{tabular}{|c|c|c|c|}
\hline & $\begin{array}{l}\text { include not transfusing, } \\
\text { prescribe iron, } \\
\text { erythropoietin (EPO), } \\
\text { vitamins, although the } \\
\text { evidence for their success } \\
\text { is limited }\end{array}$ & $\begin{array}{l}\text { (ICU4, 680) } \\
\text { "Giving iron, giving EPO, neither of which are things that } \\
\text { we do. And neither of which are things which would affect } \\
\text { the patient's haemoglobin acutely. These are longer term } \\
\text { things." (ICU8, 502) } \\
\text { "Well I mean the things we've talked about, the nutritional } \\
\text { supplements, the intravenous iron, the B12 folate." } \\
\text { (ICU11, 556) }\end{array}$ & \\
\hline & $\begin{array}{l}\text { Review or audit of current } \\
\text { practice to see if it needed } \\
\text { to change }\end{array}$ & $\begin{array}{l}\text { "...we would need a review and debate about the need or } \\
\text { otherwise for a change in practice..." (ICU4, 389) }\end{array}$ & 4 \\
\hline \multirow[t]{2}{*}{$\begin{array}{l}\text { Nature of the } \\
\text { behaviour }\end{array}$} & Routine & $\begin{array}{l}\text { "...it really should be part of the normal routine } \\
\text { management of a, for a critically ill patient" }(I C U 2,397) \\
\text { "watching \& waiting is what we tend to do" (ICU6, 170) }\end{array}$ & 3 \\
\hline & Education \& Learning & $\begin{array}{l}\text { "...we all have a responsibility to continually learn." (ICU3, } \\
389)\end{array}$ & 3 \\
\hline
\end{tabular}

Note: Clinical specialty, participant number and line number of transcript appear in brackets at the end of each quote. * Denotes domains identified as relevant. 
Table 3. Summary table of specific beliefs elicited from semi-structured interviews with 7 neonatology consultants, allocated to the 12 theoretical domains.

\begin{tabular}{|c|c|c|c|}
\hline $\begin{array}{l}\text { Construct } \\
\text { Domain }\end{array}$ & Specific Beliefs & Sample Quote & $\begin{array}{l}\text { Frequency } \\
\text { (out of 7) }\end{array}$ \\
\hline *Knowledge & $\begin{array}{l}\text { I am aware of some studies, } \\
\text { but the evidence for best } \\
\text { practice is unclear }\end{array}$ & $\begin{array}{l}\text { "The evidence to suggest how low you can } \\
\text { let it [haematocrit] go is not there" (NICU2, } \\
92 \text { ) } \\
\text { "they [recent studies] haven't changed it [our } \\
\text { transfusion practice] and they've reinforced } \\
\text { the fact that there isn't enough grounds to } \\
\text { change at the moment" (NICU5, 65) } \\
\text { "I'm aware of the Kirpalani study but not the } \\
\text { other one" (NICU6, 23) }\end{array}$ & 5 \\
\hline Skills & $\begin{array}{l}\text { Clinical skills and staff } \\
\text { management are required }\end{array}$ & $\begin{array}{l}\text { "a little bit of medicine in there..." (NICU4, } \\
647) \\
\text { “...man management rather than baby } \\
\text { management ..." (NICU8, 279) }\end{array}$ & 7 \\
\hline $\begin{array}{l}\text { Sociall } \\
\text { professional } \\
\text { role and } \\
\text { identity }\end{array}$ & $\begin{array}{l}\text { I do not feel constrained by } \\
\text { guidelines }\end{array}$ & $\begin{array}{l}\text { "No" (NICU2, 367) } \\
\text { "I don't feel constrained by guidelines } \\
\text { because I'm very particular about regarding } \\
\text { them as guidelines only." (NICU6, 166) }\end{array}$ & 7 \\
\hline \multirow[t]{2}{*}{$\begin{array}{l}\text { *Beliefs about } \\
\text { capabilities }\end{array}$} & $\begin{array}{l}\text { External beliefs } \\
\text { If the baby is at home, or } \\
\text { unstable, watching and } \\
\text { waiting is difficult }\end{array}$ & $\begin{array}{l}\text { "I would find it difficult to watch \& wait if the } \\
\text { patient was at home and I can't see them.." } \\
\text { (NICU 2, 411) } \\
\text { "I don't think it would be difficult at all as long } \\
\text { as the baby was stable." (NICU 6, 313) }\end{array}$ & 3 \\
\hline & $\begin{array}{l}\text { Internal beliefs } \\
\text { I am confident I can watch \& } \\
\text { wait }\end{array}$ & $\begin{array}{l}\text { "I think I'm very confident." (NICU3, 447) } \\
\text { "No problem" (NICU5, 392) }\end{array}$ & 6 \\
\hline \multirow[t]{2}{*}{$\begin{array}{l}\text { *Beliefs about } \\
\text { consequences }\end{array}$} & $\begin{array}{l}\text { Benefits of watching \& } \\
\text { waiting } \\
\text { Reduce infection and risks } \\
\text { associated with transfusion }\end{array}$ & $\begin{array}{l}\text { “...you might be avoiding exposing the baby } \\
\text { to..." (NICU4, 764) } \\
\text { "... avoiding exposure to the harms of } \\
\text { transfusion." (NICU5, 435) }\end{array}$ & 7 \\
\hline & $\begin{array}{l}\text { Disadvantages of watching \& } \\
\text { waiting } \\
\text { The patient's condition } \\
\text { deteriorates }\end{array}$ & $\begin{array}{l}\text { "I think the main disadvantage would be poor } \\
\text { growth," (NICU2, 635) } \\
\text { "...the baby may well be functionally } \\
\text { deficient..." (NICU7, 389) }\end{array}$ & 6 \\
\hline \multirow[t]{2}{*}{$\begin{array}{l}\text { Motivation } \\
\text { and goals }\end{array}$} & $\begin{array}{l}\text { It is important to watch and } \\
\text { wait in some situations }\end{array}$ & $\begin{array}{l}\text { "I think it is important if they are well..." } \\
\text { (NICU3, 527) } \\
\text { "We do it because we think it's important but } \\
\text { that's what we do." (NICU8, 348) }\end{array}$ & 5 \\
\hline & $\begin{array}{l}\text { It is not as important as } \\
\text { some decisions }\end{array}$ & $\begin{array}{l}\text { “...it's not as important as some decisions } \\
\text { unfortunately" (NICU4, 824) } \\
\text { "I don't think it would be a terribly high } \\
\text { priority as long as the baby was stable." } \\
\text { (NICU6, 426) }\end{array}$ & 6 \\
\hline $\begin{array}{l}\text { Memory, } \\
\text { attention and } \\
\text { decision }\end{array}$ & $\begin{array}{l}\text { The baby's whole condition } \\
\text { needs to be considered, } \\
\text { including risks \& benefits of }\end{array}$ & $\begin{array}{l}\text { "Whether the baby is ill or well." (NICU3, } \\
548) \\
\text { "...the factors that contribute to the decision }\end{array}$ & 7 \\
\hline
\end{tabular}




\begin{tabular}{|c|c|c|c|}
\hline processes & $\begin{array}{l}\text { transfusing vs watching and } \\
\text { waiting }\end{array}$ & $\begin{array}{l}\text { to transfuse the baby are multiple." (NICU5, } \\
\text { 219) }\end{array}$ & \\
\hline $\begin{array}{l}\text { Environ- } \\
\text { mental } \\
\text { context and } \\
\text { resources }\end{array}$ & $\begin{array}{l}\text { The baby's clinical condition } \\
\text { will influence whether or not I } \\
\text { watch and wait }\end{array}$ & $\begin{array}{l}\text { "...watching and waiting is harder if the baby } \\
\text { is in a significant amount of oxygen..." } \\
\text { (NICU2,607) } \\
\text { "So the clinical factors that you're looking at } \\
\text { and the clinical parameters you're looking } \\
\text { at..." (NICU6, 356) }\end{array}$ & 7 \\
\hline \multirow[t]{2}{*}{$\begin{array}{l}\text { *Social } \\
\text { influences }\end{array}$} & $\begin{array}{l}\text { We have a team approach to } \\
\text { transfusion decisions }\end{array}$ & $\begin{array}{l}\text { "...we pretty much work as a job, it's a giant } \\
\text { job share really..." (NICU2, 454) }\end{array}$ & 5 \\
\hline & $\begin{array}{l}\text { Parental opinions are often } \\
\text { sought }\end{array}$ & $\begin{array}{l}\text { "...parental wishes, fears are very much } \\
\text { taken into decision making." (NICU8, 83) }\end{array}$ & 5 \\
\hline \multirow[t]{2}{*}{ Emotion } & $\begin{array}{l}\text { I would not worry about } \\
\text { watching and waiting }\end{array}$ & $\begin{array}{l}\text { "Not at all, no." (NICU4, 866) } \\
\text { "No." (NICU5, 549) }\end{array}$ & 5 \\
\hline & $\begin{array}{l}\text { I might be concerned in } \\
\text { some situations about } \\
\text { watching and waiting }\end{array}$ & $\begin{array}{l}\text { "Well you always feel a little worried as the } \\
\text { haemoglobin starts to go down..." (NICU3. } \\
583 \text { ) }\end{array}$ & 3 \\
\hline \multirow[t]{2}{*}{$\begin{array}{l}\text { *Behavioural } \\
\text { regulation }\end{array}$} & $\begin{array}{l}\text { I would need good, new } \\
\text { evidence from research that } \\
\text { my transfusion practice } \\
\text { needs to change }\end{array}$ & $\begin{array}{l}\text { "...if there was some good, you know a large } \\
\text { body of evidence that suggested something } \\
\text { we should change..." (NICU2, 453) } \\
\text { "... a convincing piece of evidence that there } \\
\text { is a better way of doing it..." (NICU3, 334) }\end{array}$ & 7 \\
\hline & $\begin{array}{l}\text { Alternatives to transfusing } \\
\text { mainly reducing the amount } \\
\text { of blood taken - e.g. } \\
\text { reasoned sampling }\end{array}$ & $\begin{array}{l}\text { "...reduce the amount that we take out." } \\
\text { (NICU2, 513) } \\
\text { "Less blood tests" (NICU8, 240) }\end{array}$ & 6 \\
\hline $\begin{array}{l}\text { Nature of the } \\
\text { behaviour }^{a}\end{array}$ & - & - & - \\
\hline \multicolumn{4}{|c|}{$\begin{array}{l}\text { Note: Clinical specialty, participant number and line number of transcript appear in brackets at } \\
\text { the end of each quote. }\end{array}$} \\
\hline
\end{tabular}


BRITISH JOURNAI OF HEAITH DSYCHOLOGY 2009: 14, 625-64.6.

Table 4. Coding of each belief by three independent coders, and decisions for questionnaire content made on the basis of these codes (final column), for interviews with (a) critical care consultants and (b) neonatologists.

\section{(a) Interviews with critical care consultants}

\begin{tabular}{|c|c|c|c|c|c|}
\hline $\begin{array}{l}\text { Relevant } \\
\text { Domain } \\
\text { (number of } \\
\text { possible } \\
\text { constructs) }\end{array}$ & Specific Belief (ICU) & $\begin{array}{c}\text { Construct } \\
\text { (Psychologist coder } \\
\text { A) }\end{array}$ & $\begin{array}{l}\text { Construct } \\
\text { (Psychologist coder } \\
\text { B) }\end{array}$ & $\begin{array}{c}\text { Construct } \\
\text { (Physician coder) }\end{array}$ & $\begin{array}{l}\text { Agreement summary } \\
\text { (and agreed relevant } \\
\text { theories) }\end{array}$ \\
\hline $\begin{array}{l}\text { Knowledge } \\
(6)\end{array}$ & $\begin{array}{l}\text { 1. I know about the TRICC trial and other } \\
\text { evidence }\end{array}$ & Knowledge & $\begin{array}{l}\frac{\text { Knowledge about }}{\text { condition / scientific }} \\
\underline{\text { rationale }}\end{array}$ & $\begin{array}{l}\text { Schemas, Mindsets, } \\
\text { Illness } \\
\text { representation. } \\
\text { Knowledge about } \\
\text { scientific rationale }\end{array}$ & $\begin{array}{l}\text { 2/3 agree. (Knowledge } \\
\text { general and scientific } \\
\text { rationale.) }\end{array}$ \\
\hline \multirow[t]{2}{*}{$\begin{array}{l}\text { *Beliefs about } \\
\text { capabilities } \\
\text { (8) }\end{array}$} & $\begin{array}{l}\text { External beliefs } \\
\text { 2. I am confident providing the patient is } \\
\text { stable and in my care }\end{array}$ & $\begin{array}{l}\text { Control -of behaviour } \\
\text { and material and social } \\
\text { environment }\end{array}$ & $\begin{array}{l}\text { Self-efficacy } \\
\text { Perceived } \\
\underline{\text { behavioural control }}\end{array}$ & $\begin{array}{l}\text { Perceived } \\
\text { behavioural control }\end{array}$ & $\begin{array}{l}\text { 2/3 agree. (Theory of } \\
\text { Planned Behaviour; } \\
\text { Social } \\
\text { CognitiveTheory.) }\end{array}$ \\
\hline & $\begin{array}{l}\text { Internal beliefs } \\
\text { 3. I am confident most of the time }\end{array}$ & Self-efficacy & $\begin{array}{l}\text { Self-efficacy } \\
\text { Perceived } \\
\text { behavioural control }\end{array}$ & Self-confidence & $\begin{array}{l}2 / 3 \text { agree. (Social } \\
\text { CognitiveTheory) }\end{array}$ \\
\hline \multirow[t]{3}{*}{$\begin{array}{l}\text { *Beliefs about } \\
\text { consequences } \\
(13)\end{array}$} & $\begin{array}{l}\text { Benefits of watching \& waiting: } \\
\text { 4. Reduce infection and risks associated with } \\
\text { transfusion }\end{array}$ & $\begin{array}{l}\text { Consequents } \\
\text { Outcome } \\
\text { expectations } \\
\end{array}$ & $\begin{array}{l}\text { Outcome } \\
\text { expectations } \\
\text { Attitude } \\
\end{array}$ & $\begin{array}{l}\text { Outcome } \\
\text { expectations }\end{array}$ & $\begin{array}{l}\text { 3/3 agree. (Theory of } \\
\text { Planned Behaviour; } \\
\text { Social CognitiveTheory) }\end{array}$ \\
\hline & 5. Reduce costs and save resources & $\begin{array}{l}\text { Outcome } \\
\text { expectations }\end{array}$ & $\begin{array}{l}\text { Outcome } \\
\text { expectations } \\
\text { Attitude }\end{array}$ & Consequents & $\begin{array}{l}\text { 2/3 agree. (Theory of } \\
\text { Planned Behaviour; } \\
\text { Social CognitiveTheory) }\end{array}$ \\
\hline & $\begin{array}{l}\text { Disadvantages of watching \& waiting: } \\
6 . \text { The patient's condition deteriorates }\end{array}$ & Consequents & $\begin{array}{l}\text { Outcome } \\
\text { expectations } \\
\text { Attitude } \\
\end{array}$ & $\begin{array}{l}\text { Contingencies } \\
\text { Anticipated regret }\end{array}$ & $\begin{array}{l}0 \text { agree. (Theory of } \\
\text { Planned Behaviour; } \\
\text { Social CognitiveTheory) }\end{array}$ \\
\hline \multirow[t]{3}{*}{$\begin{array}{l}\text { *Social } \\
\text { influences (25) }\end{array}$} & 7. We often make decisions as a team & Team working & Team working & Team working & $\begin{array}{l}3 / 3 \text { agree. (Normative } \\
\text { Model of Work Team } \\
\text { Effectiveness) }\end{array}$ \\
\hline & $\begin{array}{l}\text { 8. Advice is sometimes sought from } \\
\text { haematologists or blood bank staff }\end{array}$ & $\frac{\text { Social support / }}{\text { professional }}$ & $\begin{array}{l}\text { Social support / } \\
\text { professional }\end{array}$ & $\begin{array}{l}\text { Social support / } \\
\text { professional } \\
\text { Feedback }\end{array}$ & $\begin{array}{l}\text { 3/3 agree. (Normative } \\
\text { Model of Work Team } \\
\text { Effectiveness) }\end{array}$ \\
\hline & $\begin{array}{l}\text { 9. We listen to the opinions of relatives, but } \\
\text { the consultant(s) make the final decision }\end{array}$ & Subjective norms & $\begin{array}{l}\text { Social pressure } \\
\text { Subjective norms - } \\
\text { Injunctive }\end{array}$ & Power /hierarchy & $\begin{array}{l}\text { 2/3 agree. (Theory of } \\
\text { Planned Behaviour) }\end{array}$ \\
\hline
\end{tabular}


BRITISH JOURNAL OF HEALTH DSYCHOLOGY 2009 : 14, 625-64.6.

\begin{tabular}{|c|c|c|c|c|c|}
\hline \multirow[t]{3}{*}{$\begin{array}{l}\text { *Behavioural } \\
\text { regulation }(10)\end{array}$} & $\begin{array}{l}\text { 10. I would need good, new evidence from } \\
\text { research that my transfusion practice needs to } \\
\text { change }\end{array}$ & Feedback & Goal setting & Action planning & $\begin{array}{l}0 \text { agree. (Control } \\
\text { Theory) }\end{array}$ \\
\hline & $\begin{array}{l}\text { 11. Alternatives to transfusing include not } \\
\text { transfusing, prescribe iron, erythropoietin } \\
\text { (EPO), vitamins, although the evidence for } \\
\text { their success is limited }\end{array}$ & $\begin{array}{l}\text { Generating } \\
\underline{\text { alternatives }}\end{array}$ & $\begin{array}{l}\text { Generating } \\
\text { alternatives }\end{array}$ & $\begin{array}{l}\text { Generating } \\
\text { alternatives }\end{array}$ & $\begin{array}{l}3 / 3 \text { agree. (Action } \\
\text { Planning) }\end{array}$ \\
\hline & $\begin{array}{l}\text { 12. Review or audit of current practice to see } \\
\text { if it needed to change }\end{array}$ & Feedback & $\begin{array}{l}\text { Self-monitoring / } \\
\text { feedback }\end{array}$ & Feedback & $\begin{array}{l}3 / 3 \text { agree. (Control } \\
\text { Theory) }\end{array}$ \\
\hline
\end{tabular}

(b) Interviews with neonatologists

\begin{tabular}{|c|c|c|c|c|c|}
\hline & Specific Beliefs (NICU) & $\begin{array}{c}\text { Construct } \\
\text { (Psychology trained } \\
\text { coder A) }\end{array}$ & $\begin{array}{c}\text { Construct } \\
\text { (Psychology trained } \\
\text { coder B) }\end{array}$ & $\begin{array}{l}\text { Construct } \\
\text { (Clinically trained } \\
\text { coder) }\end{array}$ & $\begin{array}{l}\text { Comment (Decisions } \\
\text { for relevant theories } \\
\text { did not differ from (a)) }\end{array}$ \\
\hline $\begin{array}{l}\text { *Knowledge } \\
\text { (6) }\end{array}$ & $\begin{array}{l}\text { 13. I am aware of some studies, but the } \\
\text { evidence for best practice is unclear }\end{array}$ & Knowledge & $\begin{array}{l}\text { Knowledge about } \\
\text { condition / scientific } \\
\text { rationale }\end{array}$ & $\begin{array}{l}\text { Schemas, Mindsets, } \\
\text { Illness } \\
\text { representation. } \\
\text { Knowledge about } \\
\text { scientific rationale }\end{array}$ & 2/3 agree \\
\hline \multirow[t]{2}{*}{$\begin{array}{l}\text { *Beliefs about } \\
\text { capabilities (8) }\end{array}$} & $\begin{array}{l}\text { External beliefs } \\
\text { 14. If the baby is at home, or unstable, } \\
\text { watching and waiting is difficult }\end{array}$ & $\begin{array}{l}\text { Control -of behaviour } \\
\text { and material and social } \\
\text { environment }\end{array}$ & $\begin{array}{l}\text { Perceived } \\
\text { behavioural control }\end{array}$ & $\begin{array}{l}\text { Control -of behaviour } \\
\text { and material and social } \\
\text { environment }\end{array}$ & $2 / 3$ agree \\
\hline & $\begin{array}{l}\text { Internal beliefs } \\
\text { 15. I am confident I can watch \& wait }\end{array}$ & Self-efficacy & $\begin{array}{l}\text { Self-efficacy } \\
\text { Perceived } \\
\text { behavioural control }\end{array}$ & Self-confidence & $2 / 3$ agree \\
\hline \multirow[t]{2}{*}{$\begin{array}{l}\text { *Beliefs about } \\
\text { consequences } \\
\text { (13) }\end{array}$} & $\begin{array}{l}\text { Benefits of watching \& waiting } \\
\text { 16. Reduce infection and risks associated with } \\
\text { transfusion }\end{array}$ & Consequents & $\begin{array}{l}\text { Outcome } \\
\text { expectations } \\
\text { Attitude }\end{array}$ & $\begin{array}{l}\text { Outcome } \\
\text { expectations }\end{array}$ & $2 / 3$ agree \\
\hline & $\begin{array}{l}\text { Disadvantages of watching \& waiting } \\
\text { 17. The patient's condition deteriorates }\end{array}$ & Consequents & $\begin{array}{l}\text { Outcome } \\
\text { expectations } \\
\text { Attitude }\end{array}$ & $\begin{array}{l}\text { Contingencies } \\
\text { anticipated regret }\end{array}$ & 0/3 agree \\
\hline \multirow[t]{2}{*}{$\begin{array}{l}\text { *Social } \\
\text { influences (25) }\end{array}$} & $\begin{array}{l}\text { 18. We have a team approach to transfusion } \\
\text { decisions }\end{array}$ & Team working & Team working & Team working & $3 / 3$ agree \\
\hline & 19. Parental opinions are often sought & Subjective norms & $\begin{array}{l}\text { Subjective norms / } \\
\text { Injunctive norms }\end{array}$ & $\begin{array}{l}\text { Social support } \\
\text { Social / group norm }\end{array}$ & $2 / 3$ agree \\
\hline $\begin{array}{l}\text { *Behavioural } \\
\text { regulation }(10)\end{array}$ & $\begin{array}{l}20 . \text { I would need good, new evidence from } \\
\text { research that my transfusion practice needs to }\end{array}$ & Feedback & Goal setting & Action planning & 0/3 agree \\
\hline
\end{tabular}


BRITISH JOURNAL OF HEALTH DSYCHOLOGY 2009 : 14, 625-64.6.

\section{change}

21. Alternatives to transfusing mainly reducing Generating

Generating

Generating

alternatives

alternatives

$3 / 3$ agree 